This article was downloaded by: [Temple University Libraries]

On: 22 April 2015, At: 14:36

Publisher: Routledge

Informa Ltd Registered in England and Wales Registered Number: 1072954

Registered office: Mortimer House, 37-41 Mortimer Street, London W1T

3J H, UK

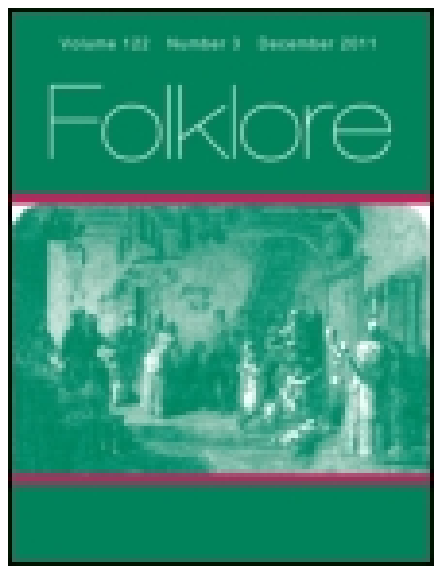

\title{
Folklore
}

Publication details, including instructions for authors and subscription information:

http:// www. tandfonline.com/loi/ rfol20

\section{Divination among the Malagasy, Together with Native Ideas as to Fate and Destiny}

J ames Sibree

Published online: 14 Feb 2012.

To cite this article: J ames Sibree (1892) Divination among the Malagasy,

Together with Native Ideas as to Fate and Destiny, Folklore, 3:2, 193-226, DOI: 10.1080/0015587X. 1892.9720105

To link to this article: http:// dx. doi.org/ 10.1080/0015587X.1892.9720105

\section{PLEASE SCROLL DOWN FOR ARTICLE}

Taylor \& Francis makes every effort to ensure the accuracy of all the information (the "Content") contained in the publications on our platform. However, Taylor \& Francis, our agents, and our licensors make no representations or warranties whatsoever as to the accuracy, completeness, or suitability for any purpose of the Content. Any opinions and views expressed in this publication are the opinions and views of the authors, and are not the views of or endorsed by Taylor \& Francis. The accuracy of the Content should not be relied upon and should be independently verified with primary sources of information. Taylor and Francis shall not be liable for any losses, actions, claims, proceedings, demands, costs, expenses, damages, and other liabilities whatsoever or howsoever caused arising directly or indirectly in connection with, in relation to or arising out of the use of the Content.

This article may be used for research, teaching, and private study purposes. Any substantial or systematic reproduction, redistribution, reselling, loan, sub-licensing, systematic supply, or distribution in any form to anyone is 
expressly forbidden. Terms $\&$ Conditions of access and use can be found at http://www.tandfonline.com/page/terms-and-conditions 


\section{DIVINATION AMONG THE MALAGASY,}

TOGETHER WITH

NATIVE IDEAS AS TO FATE AND DESTINY.

FOR more than two centuries past it has bcen well known to those Europeans who have resided for any length of time in Madagascar, that a somewhat elaborate system of divination, called Sikidy or Sikily, is practised by almost all the various tribes inhabiting the island. A good deal of information as to the modus operandi of this divination was given by Flacourt, the French governor of Fort Dauphin, in his fine work upon Madagascar published in 166r. And in later histories, such as that of Ellis in 1838 , other particulars are given, as well as diagrams of the methods by which the diviners "worked the oracle". But within the last five or six years the subject has been investigated in a most complete manner by a Jearned Norwegian missionary, the Rev. Lars Dahle, and he has given the results of his inquirics in three articles contributed to successive numbers of a magazine which I have cdited, in whole or in part, for scveral years past, the Antandnarivo Annual. I propose, therefore, to give in this paper a summary of the information Mr. Dahle has obtained, omitting many of the minuter points of philology, which would hardly prove interesting or serviceable in a paper like the present. Mr. Dahle has brought to his rescarches what no previous writer on the subject possessed, viz., a very accurate knowledge of Arabic, as well as of the Semitic languages generally, and hence he has thrown a flood of light upon what had previously been hopelessly obscure. I can therefore lay claim to no original rescarch at all in the particulars I have to lay before you; YOL in. 
all I can do is to condense from a much fuller account by this eminent scholar, and to give the most interesting facts and results he has obtained in a briefer form and for a wider circle of readers; and I shall not hesitate to quote very frecly from Mr. Dahle's articles.

One word more of introduction. The ancient religious system, or rather the religious beliefs and practices, of the Malagasy, had little to do with what we commonly understand by "idolatry". There was, primarily, a somewhat pure and lofty theism; then a development of ancestorworship, cspecially of the ancestors of the chicfs; later on, a fetishism, or trust in charms-personal, family, and tribal, becoming in very recent times a kind of national idolatry, but without anything like temple or pricstly caste, only the pricsthood of the father, the chicf, and then the sove. rcign; and there was also a firm trust in various ordcals for the detection of concealed crimes. But along with all of thesc, and in many respects much more widcly spread and more influential than any of them, was the belicf of the Malagasy in Vintana, fate or destiny, and in the sikidy, or practice of divination. The sikidy was, as Mr. Dahle's chicf Malagasy informant- "professor extraordinarius", he calls him-said, "the Bible of our ancestors", and was regarded as a divincly.given means of obtaining help and guidance in all the cvents and circumstances of cveryday life.

Mr. Dahle, in his introductory paragraph to the first paper, thus humorously describes the native beliefs in the cfficacy of divination: "If you want to look into the future, to detect secret cnemies or dangers, to find out what is to be your lnt of good or evil, the sikidy is the means of doing it. And the best of it is, that it does not, like the liates or Parecs of old, mercilessly leave you to your destiny, but kindly undertakes to avert the dreaded evils. If you are sick, the misisikidy or diviner docs not at all - like many of our modern doctors-treat you 'tenta. tivcly', which really means leaving you and nature to 
settle the matter between yourselves as best you can; neither are they shallow-minded enough to treat the case merely 'symptomatically'. As diligent men, they set to work immediately, and, as truly scientific doctors, they first try to find out the cause of the evil, and then the means of removing it. And if they can give you no other benefit in a desperate case, they will at least cheer up your spirits with a good assurance, generally terminating in a very emphatic phrase, to the effect that 'if you die, you shall be buried on the top of their head'. And even if your spirit has actually left you, they do not give you up in despair, as I shall have occasion to point out subsequently.

"I am, however, reluctantly forced to admit that I am not able entirely to exculpate my friends from the accusation that there is a slight tinge of medical heresy about them, inasmuch as their whole system of faditra (i.e., expiatory offerings or piacula) secms to rest upon the homøopathic principle, Similia similibus curantur; for the faditra (i.e., the thing the diviner ordered to be thrown away to prevent or avert an evil) was generally something that in name, shape, or number, etc., was similar to the evil in question. For example, if the sikidy brought out matty roda (' two deaths'), two locusts should be killed and thrown away, to prevent the death of two men; if it brought out mardry ('sick'), a piece of the tree called hazo marairy (' sick-trce') should be made a faditra"; and so on.

"The people had a remarkable trust in their diviners and their art; this appears even in the names by which they called them. In Imèrina and Bétsiléo (the two most important central provinces of the island), it was quite common to style them simply $N y$ mdsina ("The sacred ones'), a term which, however, did not so much imply sanctity as strength and superhuman power. In the outlying provinces-especially in the south and west-they are gencrally called ambiaisa or ombidsy, as they were also called among the Antandsy at Fort Dauphin as early as 
the time of Flacourt, and this term is the Arabic anbia, 'prophet'.

"The word sikidy (probably from the Arabic sichr, 'charm, incantation') has been gencrally translated 'divination', but it has a somewhat wider sense, as it includes both the investigation of what is secret, and the art of finding out the remedy for it, if it proves to be of such a nature that a remedy is required; but the second depends on the first. There are three kinds of sikidy which are cmployed almost cxclusively in finding out what is sccret: whilc the other kinds have.more to do with remedying the cvils. The first class, however, forms the sikidy par excellence, manipulated according to a rather intricatc sys$\mathrm{tem}$; the second class depends upon it, and secms to be of a somewhat more arbitrary character."

13efore procecding further, a word or two must be said as to the Malagasy notions of vintana or fatc, as the practice of the sikidy largely depends on these belicfs. The word vintana Mr. Dahle belicves to be an obsolete collatcral form of the Malagasy word kintana, "a star" (Malayan bintang), and, in its restricted meaning, denotes the destiny of a man as depending on the times as declared by the stars at the time of birth, and also the fitness (or the reverse) of certain times for certain actions (c.5., for a burial). The first of these was the vintana proper; the sccond was more accuratcly stylcd San-dndro (litcrally, "the hours of the day", from the Arabic sa'a, "hour", but also used in a wider sense of "any moment". As might be inferred from its name (if the above explanation of it be correct), the vintana in its turn rests upon astrology. The different days of the month, and the months throughout the year, are each supposed to be connected with different constcllations. In previous articles in the Antandnarize Annual Mr. Dahle had shown that the native names of the months are all $\Lambda$ rabic in origin, and are not, as might have becn supposed, the $\Lambda$ rabic names for the months, but the names of the twelve Signs of the Zodiac; while the names 
for the separate days of the months are the twenty-eight "Moon-stations" on which the Malagasy (originally Arabic) chronology and astrology depends. In the san-indro an important part is played by the "Seven Planets" of the ancients, that is, including the sun and moon, but excluding the earth and of course also the more distant planets, which were then not known at all. The astrologers had, however, a good deal to do outside the domain of astrology and fatc, for they had not only to find out and, if necessary, counteract the influences of nature, but also those of bad spirits and bad men, as well as of the evil eye.

Mr. Dahle divides his treatise into seven sections, a division which I shall follow in this paper, but condensing his information in many places.

I.-TIE AWAKENING OF TIIE Sikidy. The sikidy was gencrally manipulated with beans or certain seeds, especially thosc of the fano tree, a species of acacia. ${ }^{1}$ When the mpisikidy had placed a heap of these seeds or beans before him and was about to begin, he inaugurated his proceedings with a solemn invocation, calling upon God to awaken nature and men, that these might awaken the sikidy to tell the truth. The following is the formula used :-

"Awakc, O God, to awaken the sun! Awake, O sun, to awaken the cock! Awakc, $\mathrm{O}$ cock, to awaken mankind! Awake, $O$ mankind, to awaken the sikidy-not to tell lies, not to deceive, not to play tricks, not to talk nonsense, not to agree to anything indiscriminately; but to search into the secret, to look into what is byond the hills and on the other side of the forest, to see what no human eye can sce.

"Wake up, for thou art from the long-haired Sildmo (Moslem Arabs), from the high mountains, from Raborobdaka and others" (here follow nine long names). "Awake! for we have not got thee for nothing, thou art dear and expensive. We have hired thee in exchange for a fat cow with a large hump, and for money on which there was

1 Piptadenia chrysostachys. 
no dust. Awake! for thou art the trust of the sovereign and the judgment of the pcople. If thou art a sikidy that can tell, that can sec, and does not only speak of the noise of the people, the hen killed by its owner, the cattle slaughtered in the market, the dust clinging to the fect (i.e., sclf-evident things), awake here on the mat !

"I But if thou art a sikidy that docs not sce, a sikidy that agrees to everything indiscriminately, and makes the dead living and the living dead, then do not arise here on the mat."

It is cvident that the sikidy was looked upon as the special means used by God for making known His will to men; and it is at the same time characteristic enough that it was thought necessary to "awaken" God (cf. I Kings xviii, 27). In the long list of persons through whom the people are said to have got the sikidy are the Silamo (from "Islam"), chicfly Arabs, who are also called Kardiny, "readers", i.e., those who read the Kordn. Several other Arabic words occur in this invocation, as well as in the whole tcrminology connected with the sikidy, as will be noticed further on. Most of the names given above, in the list of "authoritics" from whom the Malagasy are said to have received the practice of divination, are rather obscure. Among them is that of the "Vazimba", who are supposed to be the aboriginal inhabitants of the island before the urrival of its present Malayo-Polynesian and Melanesian colonists. They may be mentioned cither because the diviners were anxious to have the sikidy connected with everything that was mystcrious and pointed back to the mythical days of old; or, possibly, because the Vazimba were really the people who first reccived the sikidy from the $\Lambda$ rabs, and that the other tribes in their turn got it from the Vazimba.

It may be added that individual mpisikidy of any repute secm cach to have had their own form of invocation, or at least made considcrable variations in the wording of it, although its gencral bearing secms to have been very much the same. 
11.-Tine Sixteen Figures of the Sikidy. Having finished his invocation, the diviner began to work the sikidy (lit. "to raise it up"), taking beans or fino sceds, and arranging them on a mat on the floor according to rules to be presently cxplained. These beans or secds must be represented by dots. They were as follows :-

\section{Hova Names.}

r. J: Jama (or Zoma)

2. Alahizany

3. $\because$ Asdraldh

4. Votsira (= Vontsira)

5. Taraiky $\ldots$...

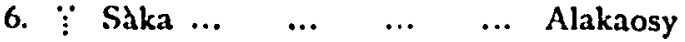

7. $\because \begin{gathered}\text { Asòravàvy } \\ \text { 6... }\end{gathered}$

8. : Alikisy $\quad \ldots \quad \ldots \quad \ldots$... Alikisy

9. $\because$ Aditsima (Aditsimay)

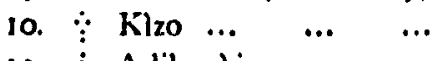

11. A. Adikasàjy ... ...

12. $\therefore$ Vanda mitsàngana

$$
\text { (= Mikarija) ... Adalo }
$$

13. $\because$ Vanda midndrika

$$
(=\mathrm{M} d \mathrm{l}
$$

14. $\because$ Alokòla

15. $\because$ Alaimora

16. Adibijady
... Alatsimay

... Alakaràbo

... Bếtsivòngo

Alahòtsy

... Alikola

... Allhimora

... Alabiào

\section{Alahamaly}

\section{Alakaosy}

Adàlo (?)

Allhimòra

Bihidva

The names in the first row are those in use in the interior; the order secms immaterial, but that here followed secms most systematic, commencing with the fullest form (:!), and taking away one bean (or dot) for each figure until only four ( $\vdots)$ are left, and then adding one again to each, by which procecding we get the first eight figures. The next eight are formed by placing twos and ones in various combinations. The theory of the whole is cridently that not more than eight beans can be used in any figure, and that all of the figures must contain four in length (or height), while there may be two or one in breadth. The names in the second and third columns were obtained from an Arab trader, and arc, several of 
them at least, casily recognisable as the Arabic names for several of the months, but for many centuries naturalised among the Malagasy; and these, as already mentioned, are the Arabic names for the Signs of the Zodiac, while others scem to be those of the Moon-stations. Mr. Dahle has minutcly examined the list of Hova names, some of which arc Malagasy, but obscure in meaning, while most of them appear to be of Arabic origin, and several are also cvidently derived from astrology; among others, the constcllations Virgo, Arics, Aquarius, Sagittarius, Pisces, and Capricornus secm to be denoted.

III.-TIE Sixtren Columes of tile Sikidy (litcrally, "The Sixteen Mlothers of Sikldy"). To the sixtecn figures, or various combinations of the beans or seeds by ones and twos in the sikidy, correspond the sixtecn columns (called by Mr. Dahle "rubrics"), places, or rows, in which they are arranged in working the oracle; one figure bcing placed in cach column, not, however, that all the figures must necessarily occur. The same figure may occur more than once, and some of the sixtcen figures may not occur at all in the sixtecn columns, as that is purely a matter of chance. If the columns are arranged in the manner usual in the practice of sikidy, we get the combination of squares given on the next page.

It will be secn at a glance, however, that we have got more than sixtcen names here, although the rows or columns are really not more than twelve, corresponding probably to the twelve Signs of the Zodiac. If a skilful diviner is asked for $N y$ sikidy $z 6$ riny', he will only enumerate the names given in the first (top) row (Tale-Vd/itra), the four to the right of it (Zattvo-Fdhavdlo), and the cight bclow (Trdno-Fd/asivy), giving us the sixtecn complete. The others secm to be considered as accessory and of sccondary importance. Some of them are simply repetitions, with this difference, that they refer to things in another person's housc, not in that of the inquirer for whom the sikidy operation in question is undertaken 
Others are placed to the left side of the lower square, and others at the six corners.

Mr. Dahle proceeds to investigate each of the thirty-four words shown in the diagram; and points out that while the majority of them are Malagasy, about four or five are evidently Arabic. The Malagasy words are those in urdinary everyday use, as those for wealth, relations, village, youth, woman, enemy, house, road, inquirer, God,

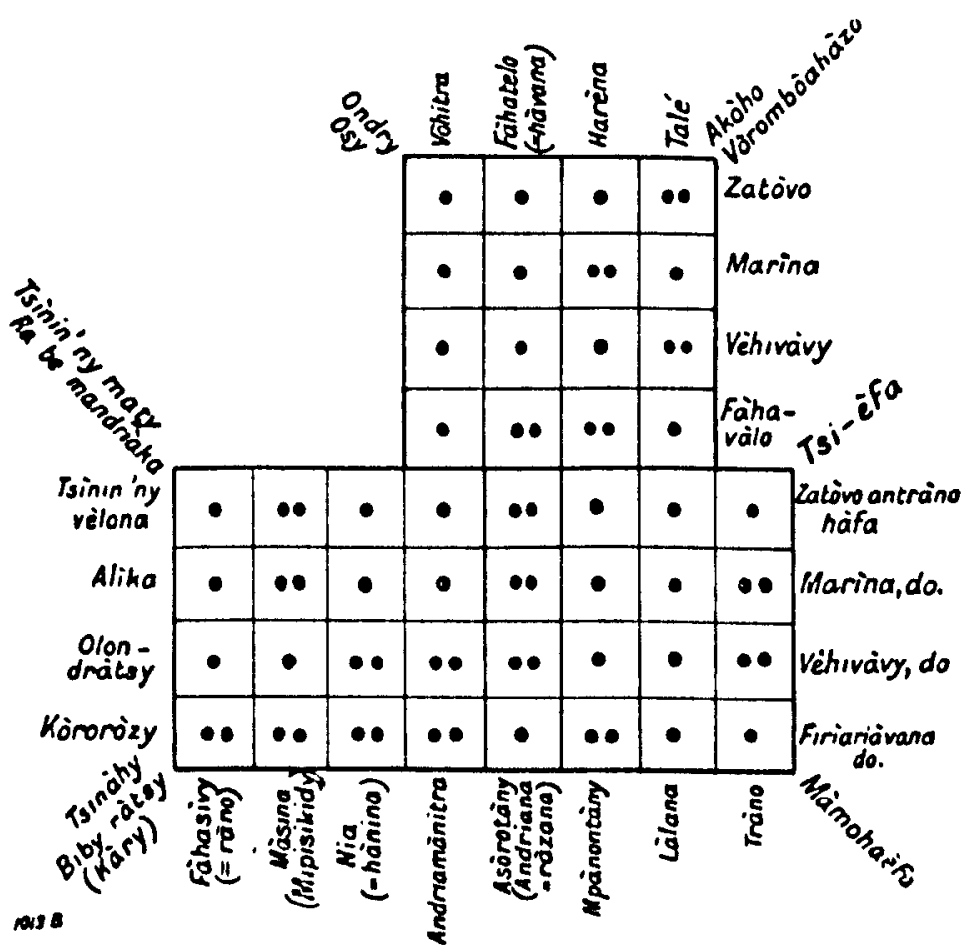

Arrangement of Columne in the Sikdy Divination.

diviner, wild-cat, dog, shcep, goat, fowl, much bloodshed, etc. Of the four or five derived from the Arabic, the first word, Tali, apparently meaning "investigator" or "explorer", always represents in the sikidy the person or thing concerning whom (or which) the inquiry is madc.

In reading or examining the columns, the first four (Talt-Vdhitra) and the cight below (Trino-Fdhasivy) are read from above downwards. The cight to the right 
(Zaldvo-Firiaridvana) are read from right to left. The four to the left (Korordsy-Tsinin' ny velona) are read from left to right, while the names at the corners are read diagonally.

IV.-Tile Erecting of TIIE Sikidy (i.e., the placing of the figures in the columns). So far, we have only scen the machinery, so to sycak, with which the divination is worked; now let us try to understand how the diviner procecded in order to gain the information desired in the great varicty of inquiries made of him. In the diagram here given, all the columns are filled with figures, just as a veritable mpisilidy would do, except that dots are used instead of beans or sceds. "The rulcs for "crecting the sikidy" will now be given.

1. The first four columns (Tale-Vd/itra) are filled with figures in the following manner. From the heap of beans before him the mpisikidy takes a handful at random, and from this handful he takes out two and two until he has cither two or one left. If two are left, he puts two beans, if onc, one bean, into the first or upper square of Tale. In the same manner he fills the remaining three, Hardna, Fithatdlo, and Volitira, square by square, from above downwards.

2. When these four columns-one of which represents the person or thing regarding whom or which the sikidy is madc-are filled in the manner described, the remaining cight are filled by a combination of these first four, or of others that have already been filled by a combination of thesc. This is done in such a manner that two figures are chosen and compared square by square from above down. wards. If this combination gives an odd number (i.e., if one of the two combined squares has one bean, and the other two), only one bean is put in the corresponding square of the new figure to be formed; but if it gives an cven number (i.e., if the two combincd squares both contain onc bean, or both two beans), two beans are put into the new figure. 
3. These combinations arc subjected to the following rules :

(a) Tale and Harina (i.e., a combination of the two in the manner described) form Làlana.

(b) Fdhatelo and Volitra form Asorotdny.

(c) Lalana and Asorotany form Mpdinontiny.

(d) Zatòvo and Marina form Nia.

(e) Velhiz duy and Fdhavalo form Fdhasivy.

(f) Nia and Fdhasivy form MIdsina.

(g) Midsina and Mpinontdny form Andriamdnitra.

(h) Andriamdnitra and Tale form Tràno.

A glance at the diagram here given will show that all the eight figures below have actually been formed according to these rulcs. If we, for instance, compare Tale and Harcna, from which Ldlana is to be formed, we get dissimilar numbers all the way, as all the pairs of squares have one and two, and consequently Ldlana gets only one bean in all its squares. Exactly the same procedure-mutatis mutandis-takes place in the filling in of the remaining seven columns below.

v.-TIIE Working of tile Sikidy.-When the sikidy is "erceted" or arranged in the manner just described, the question arises: What is to be done with it? How to work it so as to get an answer to your questions, a medicine for your sickness, or a charm against the evils of which you may be apprehensive, ctc. ?

Let it be remarked at the outset, that the sikidy properly deals with questions put to it. To answer these is its proper function. But if you ask what is the root of an cvil, or the means of removing or averting it, ctc., the answer will of course point out to you the cure of your evils, as well, and so far, appear as ars medica. There arc, however, kinds of sikidy in which no question is put, but the remedy for the evil is prescribed at once. But as these are rather different from the ordinary sikidy-process, they will be noticed in a separate section. What conecrns us now is, 
the ordinary sikidy, the business of which is to give answers to our questions.

The first thing to be done, after having "crected the sikidy", is to sce what figure we have got in the column named Andriamdnitra (God); for, out of the sixtcen figures, only half of them (Nos. 1, 3, 5, 7, 9, 12, 13, 14) are considered to "agrce" with Andriandnitra. These are called the "Nobles" or "Kings" of the sikidy, whereas the remaining cight are called its "Slaves". If any of these latter figures happen to get into the said column, the sikidy becomes invalid, and the whole has to be broken up and commenced ancw; for the sikidy has not done proper honour to God in putting a slave in His column, and cannot be expected to tell the truth in His name.

This point, however, being successfully arranged, the next business is to choose one of the four first columns (Tale-Vdhilra) to represent the question, or, rather, the person or thing it refers to. As Tale is to represent cverything that cannot be put under the headings "property", "rclations", or "village", the choice cannot be very puzzling ; but this being settled, the proceedings branch out into the following parts, which Mr. Dahle terms: (A) The Sikidy of Identical Figures; (B) The Sikidy of Different Figures; and (C) The Sikidy of Combined Figures.

A.-The Sikldy of Identical Figures.-Having settled which of the four first columns is to represent the question, the next thing is to examine which of the sixteen figures happens to be in the column representing it. This being found, we go on examining all the other figures except the others of the first four (for these have nothing to do with the answer), that is to say, those on the right side, those on the left, and those on the two corners to the left.

If wc, thus examining them, find that any of them is like the one representing the inquiry, this may or may not scttle the question, or, in other words, give us the answer. This depends on the nature (name) of the column in which it is found. This Mr. Dahle illustrates thus: "If I expect 
a ship, and am going to inquire about its coming by means of the sikidy, the column Harena (or property) will of course represent it. If in this column I find, for instance, the figure Jamd ( $\vdots \vdots)$, and on further examination find the same figure in the column Trano (house), this gives me no answer, as there is no natural connection between the two conceptions. If, on the contrary, I find the same figure in the column called Lalana (road), then of course 1 know that the ship is at any ratc on the way. I have then got an answer to the chief question; but there may still be good reasons for a sharp look-out, for there may be diffculties in its way. Suppose that I also find the same figure in the column named Fahavdlo (enemy), my mind will immediately be filled with gloomy apprehensions of pirates! Not a bit more checrful will be my prospects if 1 find the same figure under Ka be mandriaka (much bloodshed). But what a consolation, on the other hand, if the same figure reappears in the column Nia (food); for then I must certainly be a blockhead if I do not understand that, although the ship may have a long voyage, there is no scarcity of food on board; and so on. It is casy cnough to sce that a man with much practice and a good deal of imagination could produce much 'information' in this manner; and I suppose that in a good many cases the mpisikidy were able to find an answer already in this first act of their procecdings, even if the means of finding it might scem scanty enough to ordinary mortals."

But there is much more still that may be done; for, besides the answers available from the fact of the identity of the figure representing the question with one or more of those in the other columns, it is of great importance to find out whether any two or more of the other figures are alike, and in how many columns the samc figure occurs in a sikidy. The detailed particulars given by Mr. Dahle on this point may be put for the sake of brevity into a tabular form : 
Columas soith same Figures. Native Word for

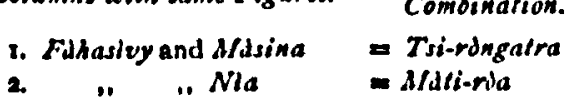

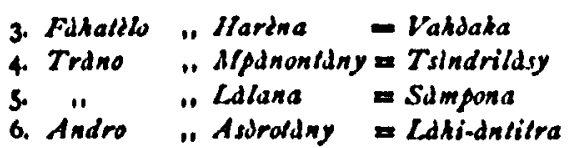

Meaning.

z does not move or agitate.

$=$ two deaths; that is, two will die, but two locusts may be thrown away as a faditra or piaculum. = a crowd of people.

- enemy approaching.

$=$ hindrances expected.

= old man; that is, the sick will recover, and reach old age.

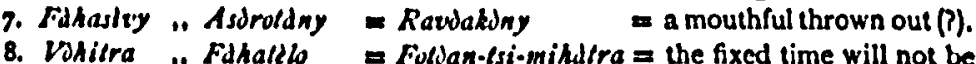
kept. 9. Ldlana "Nla = Fhi-lsi-rbso = the troops will not

The following five possibilitics refer to somewhat dif. ferent cases, thus :

10. If the figure Alokdla ( $\because$ ) occurs three times in different columns, three stones are to be thrown away as a foditra to avert evil.

11. If Valnda milsdngana ( $\therefore$ ) occurs three times, the feathers of a white hen are to be a faditra.

12. If Alaimdra ( $i i$ ) occurs twice, it means that the son of a mighty man is likely to be a mighty man too.

13. If Sika ( $i$ ) occurs in Trdno, and Vontsira (i) in Talk, or Alaimdra $(\because i)$ in Trino, and Adibijidly ( $\because)$ in Tall, the case will follow the analogy of the one preceding it ; e.g., if my child, who was formerly ill, was cured, this one will be cured; if it died, this one will die too.

14. If a sitidy happens to contain eight Vontsira (. ) they are called "the eight healthy men", and are considered an excellent remedy against disease, as will be showa later on.

It is cvident that many of these "meanings" can be construed into answers to questions, although the general tendency of many of them secms to be rather to point out the fdditra to be used against the cvil. But it might happen that the figures were all unlike one another, at any rate that those which were like the one in the column re. presenting the question were so incongruous with it that cren the most inventive imagination and the greatest acuteness, sharpened by long practice, would prove unequal 
to the task of construing it into a reasonable answer to the question. In such cases the mpisikidy was obliged to have recourse to other operations, viz., the Sikidy tokana and the Lofin-tsikidy, of which the first one is comparatively simple, while the latter one was very complicated. Each of these will now be briefly explained.

B.-The Sikidy of Unique Figures.-If it happens that any of the twelve principal columns (Tale-Volitira and Trdno-Fdhasivy) gets a figure which does not occur in any of the other columns, this is called Sikidy tokana, "a sikidy that stands alone"; and conscquently there are twelve possible kinds of this species of sikidy. Often many of the columns may happen to have unique figures; in the diagram, for instance, Masina, Asdrotany, Trdno, and Tald have each one occurring in no other column. But it would be remarkable (although it is possible) if all the twelve columns got different figures, so that all the rules for sikidy tokana became applicable in the same sikidy.

The twelve columns are enumerated in a certain order by the diviners. First comes Andriamdnitra (God), then the four at the top of the diagram, and finally the seven remaining ones below. In all the twelve classes of sikidy cokana the meaning depends on which of the sixtecn figures it is that occurs as unique in the column in question. In many cases only a few of them have any special meaning attached to them, as will appear from the following rules regarding cach class :

1. Unique Figures in the Column Andriandnitra.-As only eight of the figures can be placed in this column without making the whole sikidy invalid, as previously mentioned, we only get cight varicties :-

(a) If figure 9 occurs, it denotes that a thing can bc done seven times without any hindrance.

(b) If figure 7 , you must throw away a cooking-pot full of rice, and you are likcly to get rich.

(c) If figure 3 , which is here called Mathatsingana, is 
taken (i.e., the beans composing it) and applied to a recd (vdlotsdngana) of the same length as the man for whom the sikidy is worked, and this is thrown away, it will bring good luck.

(d) If figure 14 , it is an excellent charm against gunshot (ddi-bisy).

(c) If figure 13, the beans composing it are taken and mixed with a herb called tambindana; the sick person licks this six times, and it is then put on the top of his head.

(f) If figure 12 (here called Heloka, guilt), the six beans of the figure are placed on as many ricehusks, which are then thrown away as a fdditra.

(g) If figure 1, a tree called dndrardzina (a species of Trema) is to be the fiditra.

(h) If figure 5, a white hen and a tree called fotsinanalidry (" white one of the Creator") are to be the faiditra.

2. Unique Figures in Tale.-This is the only column in which all the figures have a special meaning; but as they are much in the same style as those already given under Andriamduitra, it would be tedious to give them in detail. Mr. Dahle observes here: "I do not intend the reader to practise the sikidy (this secret I shall of course kecp for iny own use 1), but only wish to give him an idea as to what it is."

3. Unique Figurcs in the olker Columms.-In the other fourteen columns the number of figures having special meanings varies from one to fourtecn out of the sixteen possibilitics; but space and time do not allow any further details, especially as their gencral character is shown by the examples given under Ardriamdnitra. Most of them simply suggest an answer to a question, frequently also giving a remedy against the evil intimated by the answer. As a specimen, however, it may be mentioned that when the figure Sdka occurs singly, in the column Trdno, it is 
considered as an excellent remedy for sterility if the five beans of the figure are mixed with milk, which is then to be put into fourteen fragments of pumpkin shell, and given to fourteen children, who are then to put some rice into a pot, from which the sterile woman eats it. Many of the rules in this kind of sikidy refer to sterility, sickness, or death.

Under this section of Unique Figures, Mr. Dahle describes two other kinds of sikidy which are closely connected with the preceding ones, and called respectively (I) "Sikidy mutually corresponding", and (2) "Sikidy providing a substitutory sacrifice".

1. In the first of these, when certain figures occur in certain columns, clods of earth squeezed out from under the feet must be thrown away as a fdditra to prevent one's self being crushed; while in other contingencies two hens are to be beaten against the ground to prevent evil.

2. The second kind of sikidy just named is a more important operation, and seems chiefly to have had the office of intimating that some young man was in danger of dying ; and the rulcs accompanying it point out the means of averting the evil. If Alaimdra is the unique figure in a sikidy, and happens to occur in the column Fdhavdlo, this is called MIdsodndro manddlo (" the passing sun"), intimating the danger of some man dying; and the following is the procedure resorted to so as to avert the evil : A red cock is fetched and adorned with crocodiles' teeth and a piece of bark of the ndto trec, which has been soaked in boiling water for a night. This cock is brought to a place to the cast of the house a little before sunrise, and is put on a ncw mat on which no one has yet slept. The diviner who is to perform the act must wear a red ldmba (a garment very much like the Greck opiblema or himation and the Roman antictus), and a piece of black cloth on the back, both new, and at any rate not sewn or mended. The man for whom the sikidy is worked must place himself on a similar mat in the house and wear a similar dress. As soon as the sun 
rises the diviner cuts off the head of the cock, enters the house with the bloody knife in his hand, and touches with this the person for whom the sikiddy is made.

If Alaimbra comes into Tale and Adibijddy into Faha. sivy, or Adibijddy into Fahasivy and Alaimbra into Tale, it is called Ldhi-linjana ("the strong one"), and the mcaning is that a son of young parents is likely to dic young, if some effective remedy is not resorted to. And this is the remedy: Two young bullocks' horns (onc from the right and one from the left side of the head) are taken and placed on the top of a picce of a trec called hdzo-bjka (i.e., "the leprosy-trce"), which is then crected close to a river, so as to throw its shadow on the water, and a trench is made from the water up into the land. Then the man for whom the sikidy is worked enters into this trench, and through this into the water. Finally, an assistant takes.the stem of a banana-tree of the same length as the man for whom the sikidy is worked, puts it into the trench, and joins the diviner in offering a prayer that the banana-stem may be accepted as a substitute for the person, and that he may live long. About sunset the man is sprinkled with two kinds of consecrated water, and the procecdings are at an cnd.

C.-The Sikidy of Coubined Figures.-It may happen that ncither of the two classes of divination already described gives any reasonable answer to the questions, and then this third kind (Ldfin-sikidy) is the final resort. The general rules for this operation are the following :-

1. The figures in any two columns of an ordinary sikidy (like the one given in the diagram) may be cumbined in the very same manner as that by which all the lower columns were filled from the four upper columns in it.

2. These new figures must of course be like some of the sixtecn figures already cnumerated (sce tablc, p. 199); but the columns they occupy get new names, and consequently give material for fresh answers. Their names do not however, depend on what figures come out, but from 
what columns (i.e., from what combinations of columns) they have been derived. For instance, if the figures in the two columns Fahasivy and Andriandnitra in the diagram are combined square by square, the new figure would be an Adibijddy ( $\because:)$, but this new column would always have the name Lizabi ("grcat calamity"). Another combination would give the name to a new column called Rèsy ("conquered"); and so on.

3. But there are also other possible combinations, viz. :-

(a) A part only of some columns may be combined with a part of other columns.

(b) One of the columns in the diagram may be combined with one of the new ones.

(c) Two of the new columns may be combined with one another in the same manner.

But these combinations are not done at random; on the contrary, they are subjected to strict rules, stating clearly which two columns can give birth to such and such a new onc. In this manner Mr. Dahle's native helper gets $8 \mathrm{I}$ new columns (besides those in the diagram), subjected to as many rules, and contributing matcrials for as many ncw answers to questions. To give these in full, with their various meanings, would occupy a considerable treatise, and the above may probably be considered intricate enough. This sikidy, says Mr. Dahle, reminds him of the Danish proverb, "Deceit is a science, said the Devil, when he gave lectures at Kiel." A long list of rules (23 in number) is given by native professors as to the proper means of obtaining faditra or piacula for the different evils to be averted.

vi.-Miscellaneous Sikidy.-In all the varietics of sikidy hitherto dealt with, the chief object in view has been to get an answer to questions, while it has been only a secondary and subordinate object to find out the remedies against evils, that is, if the answer informed us that some evil might be apprehended. But now we come to some sikidy practices, the chief object of which was to remedy the evils, or 
to procure a proplyylactic against them. In other forms of this miscellancous sikidy the object aimed at was to find times and dirctions when and where something was to be found, or was to takc place.

A.-Ody bdsy (charms against guns).-These must be of comparatively recent origin, as guns have not been known in Madagascar for more than threc centuries, but it is probable, from certain formula still made use of, that they were anciently spear-charmes. The following were the rules for obtaining such charms :-

1. Such a sikidy must invariably be worked on the last one of the two days of each month which took their names from the month Addlo, because the object of the charm was to make the musket ball (or spcar) manddlo (i.e., pass by, without hitting) the person for whom the sikidy was made. (Here was an instance of a kind of homœopathic principlc, of which Malagasy folk-lore and plant-lore and charms present innumerable cxamples.)

2. The rules for crecting this sikidy were very claborate, as the great object was to get one in which the figure Adit-

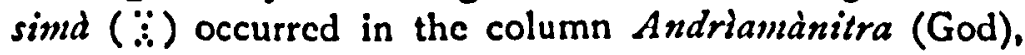
and in no other column. If this did not happen, the diviner had to erect the sikidy ancw over and over again until it did occur. And as he must have seven such sikidy, it must have taken a very long time before the business was finished, if the arrangement was left to haphazard. But a good diviner was of course supposed to be inspired, and then he may have hit upon it at once.

3. The seven beans were put into the object (in many parts of the island, a picce of bullock's horn) to be used as a charm, and this was worn on some part of the person, often bound round the temples. Mr. Dahle belicves the word Aditsind to be a corruption of the Arabic al-limd, "the protected one"; and so possibly means "protection from God", reminding him of the Arabic saying: "Nobody is infallibly protected except' God and His prophet" (i.e., Mohammed). 
B.-Odim-bdrotra (trade-charms).-These were used to make trade successful. They were effected by erecting a sikidy in which there occurred eleven Adikastjy ( $\vdots$ ). The beans of these eleven identical figures were then applied to the things to be used as charms to make trade prosperous.

C.-Odim-pitia (love-charms).- These were prepared by erecting a sikidy in which the figure Vontsira ( $\vdots$ ) occurred in the column Harina (and nowhere else), and the figure $K i z o(\because)$ in the column Nia (and nowhere else). The first of these was called Mamy d/lo ("I am sweet"), and the second Kely mdnba ny nd/kiny ("small, but sticks to what is intended"). These charms were also used as tradecharms, as the great object in view in trade also is to make the customers "love" (that is, like) the things sold.

D.-General charms.-If a sikidy was erected in which the figure Vanda miondrika ( $\because$ ) occurred only in the column Andriandnitra, this was a good general charm for everything.

E.-Fanindri-lda (charms against vomiting).-The diviner arranged his beans so as to make a rough figure of a man. Then he gathered them together and mixed them with a decoction of two plants and made the patient drink the mixture.

F.-Odin' ny dlona tdhina (charms against dislike to food). - Here is a useful prescription for those whose appetite is failing. The diviner arranges his beans so as to make four different figures. These are then mixed with water, which is drunk by the person in question, and the cure is complete. At any rate, says $\mathrm{Mr}$. Dahle, the diviner did not, he believes, mention a single case in which it had failed!

G. - Fangaldn-kio (remedy for diseascs caused by cating food in which there was a Matdatda, the spirit of a dead man); and

H.-Fampodian' dloka or ambirda (the bringing back a semi-departed spirit).-Time and space forbid that I should give in detail the strange mixture of chance and jugglery by which the diviners professed to be able to effect the 
operations denoted in the names of these two species of divination. In the second of them not only were beans composing various sikidy used, but also a number of other objects were with them pounded in a mortar by the afflicted person, while an invocation was addressed to God.

I.-Andron-fdny (lit. "days of the land", but in the sense of the different quarters or directions of the compass, as expressed by the place in the house assigned to each day). - What is really meant by this somewhat indefinite heading is, the art of finding out in what direction you are to seck for a thing that is lost, stolen, or strayed, ctc. And this is denoted by the sikidy bringing out a certain figure in a certain column, showing that the thing wanted was to be looked for in a certain dircetion. For in the old native houscs, which are always built with the length running north and south, and the single door and window on the west side, the names of the twclve months are given to twelve points of the compass, four at the corners and two on each sidc. (Sce diagram given later on, under San-dndro, p. 222.) For instance, if the sikidy brought out a figure which pointed to the south-cast, the diviner did not call it so, but said it pointed to Asorotany, i.e., the constellation Cancer and also the name of a Malagasy month, which, in the arrangement just mentioned, has its place assigned to it at the south-eastern corncr of the housc.

J.-Andro forsy (lit. "white days", i.e., the days on which something expected or sought for was to happen).Suppose, says Mr. Dahle, I have lost a slave. It is of the utmost importance to me to know on what day I shall find him ; for then I do not trouble myself about scarching for him before the day is comc. Consequently I go to the diviner. He knows that certain combinations in certain columns denote the different days of the week; and if, for instance, these columns prove to be Harina and Fdilasivy, then he knows that what he asks about will occur on Wednesday (Alarobia). And so with the other days of the weck 
Mr. Dahle remarks here: "It is easy to see that this was a very convenient way of saving much time and trouble. Suppose I expect a friend from Fianàrantsò on Monday, but he may have postponed his departure from that place, or he may have been delayed on the road; well, I go to the mpisikidy, and he tells me that he will not arrive before Saturday. Fancy now that I had not been prudent enough to do so ; what would have been the consequence? To say nothing of other inconveniences, my wife would certainly have kept the dinner ready for him from noon to night every day from Monday to Saturday ; and if she had not been an angel-which, of course, she is-she would certainly have looked very cross when he at last appeared. What a blessing these mpisikidy must have been, especially in the good days of old, where there were no doctors and no telegraphs!"

It has frequently come before our notice in the preceding sections, that all depended on what figures were placed in each column by the erecting of the sikidy. And as the first four columns were filled in a manner which secms to have depended entirely on haphazard, and the filling of the others depended on these four, we should conclude that nothing so far was arbitrary, and that the mpisikidy had no control over the form of the silidy, nor could he decide beforchand what figures would occur in each column. "But", says Mr. Dahle, "I understand that sometimes (eg., in producing love-charms, trade-charms, etc.) he took the liberty of filling the first four columns with figures which he knew beforehand (from theory and experience) would, in the further procedure, produce exactly the figures he wanted, and in the columns he would want them, for the sikidy in question. How else could he have got a sikidy in which Adikasdjy ( $\because$ ) occurred cleven times? or in which Vontsira (:) occurred eight times? or in which Vontsira came into Harena, and Kizo (: $:)$ into Nla, and nowhere clse? I believe he would often have had to erect his sikidy some thousand 
times before that could 'happen', if he did not 'make it happen' in the manner intimated above. No doubt he gencrally began working on the haphazard principle; but after having destroyed his sikidy several times and begun anew-just sufficient to make his spectators understand that it was a very scrious affair-he had resort to artificial means, and made it suececd. I fancy this was the general practice in producing the charms described above."

Mr. Dahle thinks that the practice of sikidy among the coast tribes is not so fully developed as that in use in the interior of Madagascar, except, possibly, in the district of Matitinana (S.E. coast), for here there was an ancient Arab colony, and a great many Arabic customs have been retained by the Antaimoro, as well as by the Antandsy, further south towards Fort Dauphin, where Flacourt was governor.

The Bétsimisdraka have, besides the systematic kind of sikidy already described (Sikidy alinana), at least six other kinds. These are said to be much simpler than the ordinary kind of divination; one, for instance, has only two columns or rows ; another kind, also with two columns, is worked by using in some cases three beans, as well as one or two. Other kinds, although styled Sikidy kofáfa or viro, can hardly be properly called sikidy at all. The procedure is simply the following: You take an indefinite number of kiofifa or viro (kofafa, a broom made of grass stalks, vero, a tall grass), and you then take out two and two until you have only one or two left. But you must have settled in your own mind at the outset whether one left shall mean good luck, and two bad luck, or vice versa. A similar practice is, we know, found among Europeans also, but only as an amusement.

There is, says Mr. Dahle, another kind of sikldy (if we like to call it so), which, I have been told, is practised by an old woman in Antandnarivo. Something had been stolen and nobody knew the thicf, but they suspected he was to be found among the servants. So the old 
woman said: "Look here, I will show you who has stolen it. Let each of you bring me a little piece of wood." This being done, she cut all the pieces exactly the same length, gave them back to the people, and said: "After a little while, you must all bring me your pieces, and you will see that the one belonging to the thief will have become a little longer than the rest." But when they brought their picces, lo I one of them had become a little shorter than the rest; for the man who was conscious of being guilty had thought it best to secure himself by cutting off a little of his piece, which was exactly what the sly old woman had calculated would take place. So the thief was found out. This was smartly done, but it can hardly be a common practice, for, if so, it would become known, and conscquently be useless. ${ }^{1}$ For ordinary cases of this kind the Ali-pdko, so much in use here, would work better.

The Ati-pako, here mentioned by Mr. Dahle, is thus described in the Malagasy-English Dictionary: "A mode of recovering stolen property without detecting the thief; all the servants or employeses are required to bring something, as a small bundle of grass, ctc., and to put it into a gencral heap. This affords an opportunity to the thief of secretly returning the thing stolen."

vIl.-We now come to the last division of our subject, viz., that of VinTANA and SAN-ANDRO, or, as Mr. Dahle thinks this section might be termed, (1) Zodiacal and Lunary Vintana, and (2) Planetary Vintana.

A.-What, then, is vintana? If a man was ill, pcople often said, "Perhaps the vintana of his son is too strong for him, or he has become subject to some misfortune," so they said, "Vintany izdny angd/za" ("Perhaps that is his vintana"). Or perhaps he was perpetually unsuccessful in business, and they said, "Olona rdtsy vintana iedny" ("That

1 A similar practice is found among Oriental peoples; see an exactly parallel account to the above in Rev. Dr. Thomson's The Land and the Book, $1883 \mathrm{~cd} .$, p. 153. 
man must have a bad vintana"). Even immorality (eg., an unmarried woman becoming pregnant) was excuscd by the remark, "Vintany liainy angdha izdny" ("Perhaps. that is her vintanc"), meaning that there was no helping it.

Now what docs this all mean? Vintana scems like the fatum of the Grecks and Romans, an invisible power that made itsclf felt always and cverywhere. The following views seem to be implied in the Malagasy ideas of it.

1. Earth is not governed by itself, but by heaven. Not only is the succession of day and night settled by the most glorious heavenly bodics, the sun and the moon, but the fitness or unfitness of times and scassins for various. things to be done, as well as the destiny of man himself, depends upon the heavenly bodics.

2. As far as mankind is concerned, the stars forming the constellations of the Zodiac are all-important. Their influence is manifested in two respects : they decide the destiny of a man, and also the fitness or otherwise of times and scasons.

3. The destiny of a man (his vintana) depends on what day he was born (partly also on what time of the day), or, rather, on what constellation of the Zodiac governed the day of his birth. It was therefore incumbent upon the "mpaniutana (those who dealt with the vintana), or the mpandudro(day-makers or declarers), who were also diviners, to inquire about the day or time of the day of a child's birth in order to make out its vintana, i.e., under what constellation it had been born, and what influence this would have on its destiny.

4. As the names of the constcllations of the Zodiac also became the names of the months, and of the days of the month (at least in the interior provinces), it is not clear what infuence was attributed to the moon; but that it was not considered to be without some influence appears from the following facts:-(a) Although the days of the months had scemingly borrowed their names from the 
constellations of the Zodiac, they really represented the 28 "Moon-stations" of the Arabs. In Flacourt's time (230 years ago) these were still retained on the south-east coast, ${ }^{1}$ but in the interior of Madagascar they have becn superseded by a somewhat simplified nomenclature, that is, by simply calling them first and second, or first, second, and third (or equivalent names), as the case may be, of each month, Aldhamady, Adaoro, and the rest. ${ }^{2}$ (b) The Malagasy year was a lunar one ( 345 days). And $(c)$ both the sun and the moon take their place as governors of the days of the week.

5. Besides the division of the year into months, the Malagasy have from time immemorial known a hebdomadal unit, the week, the days of which have Arabic names. These days were thought to be under the special influence of the "Seven Planets" (i.e., what were by the ancients so called, viz., the Sun, the Moon, Mars, Mercury, Jupiter, Venus, and Saturn), as will be noticed presently under Sanandro.

"It is casy to sce", says Mr. Dahle, "that the whole life of a Malagasy would be thought to be under the influence

1 Here, for example, are the three Moon-stations in Alahamady : (1) As-sharatani, (2) Al-butaina, (3) Az-zurayya, or names of the first three days in every month.

The following are the Malagasy month-names, with their Arabic derivations and equivalent Zodiac signs :-

\begin{tabular}{|c|c|c|}
\hline Malagasy. & Arabic. & Zodiac Signs. \\
\hline 3. Aldhamady & Al-hamalu & $=$ Aries. \\
\hline 2. Adaoro & $\Lambda t z-t z n u r u$ & $=$ Taurus. \\
\hline 3. Adizaoza & Al-dsehauza'u & $A=$ Gemini. \\
\hline 4. Asórotàny & As-saratanu & $=$ Cancer. \\
\hline 5. Aldhasdty & Al-nsadu & = Isomajor. \\
\hline 6. Asombola & As-sunbulu & $\begin{array}{l}\text { - Spica in Virgo, which constellation } \\
\text { it represents here. }\end{array}$ \\
\hline 7. Adimizana & Al-mizana & $=$ libra. \\
\hline 8. Alakardibo & Al-aqrabu & $=$ Scorpio. \\
\hline 9. Alakaosy & Al-qausu & = Sagillarius and arcus. \\
\hline 1a. Adijady & Al-dschadiu & = Capricornus. \\
\hline 11. Adalo & Ad-dalvu & = Aquarius. \\
\hline 12. Alohotsy & Al-hutu & $=$ Pisces. \\
\hline
\end{tabular}


of these heavenly bodies, and consequently at the mercy of those who are supposed to understand these often very intricate affairs. Pcople are generally under the spell of those who know their destiny beforehand (while they do not know it themselves), who have the power of remedying the cvils of it, and are able to tell them both what they ought to do, and when they should do it. When we remember the great influence that astrologers had over emperors, kings, and princes during the Middle Ages, and cven far into the 17th century, we can casily understand what powers they must have had (and still have) in a country like Madagascar."

With regard to lucky and unlucky days, the following remarks may be made:

1. Although the different months were thought to have their peculiar character (according to the constellations they were named from) and their special piacula and offerings, ctc., it docs not appear that one month was considered more unlucky than another. The difference in this respect was a difference between the different days of the month; which, it must be remembered, were named after the month-names also, cight having two, and four threc, days respectively allotted to cach, as ist, 2nd, and 3 rd of Aldhamddy; Ist and 2nd of Adaoro; and so on, but each of the twenty-cight being also called by the names of the Mfanazil-ul-kamari, or moon-stations.

2. The characters of the days evidently did not depend so much on from what month-name it took, as on what moon-station it represented. Therefore we often find two successive days with the same name common to both, of which one was considered good, the other bad. $E_{g}$, the ist and 2nd of Asdrotany were good, and were, and are still, favourite days for fdutadilana (the ceremony of removing corpses (rom an old family grave to a new onc); but the 3 rd day was considered bad.

3. Some days were considered absolutely bad; e.g., the 3rd of Asdroting the 2nd of Asombola, the 2nd of 
Alakaosy, and the Ist of Adijady ; others were absolutely good, eg., the three days called Alàhamddy, and the 2nd of Alakarabo; others again were considered indifferent, e.g., the ist and 2nd of Alahasaty.

4. Some days again were not considered good in general, but still good enough for special purposes ; e.g., the ist of Alakardbo was excellent for a house-warming; the 2nd of Adijady was good for marking out the ground for a new town; and the 3 rd of Adimizana was a lucky day to be born on, but a bad day for business.

5. Some days had a special peculiarity of their own; e.g., children born on the 2nd of Adalo gencrally became dumb! so they say.

6. Even the bad days were generally so only in the sense of having too strong a vintana. This was especially the reason why children born on these days werc considered a very doubtful gift. Hence the infanticide in former times in the central provinces of Madagascar, and still practised in most parts of the country where Christianity has not yet been taught. Sometimes, however, the diviner managed to remedy the evil in one way or another; and occasionally nothing more was requircd than to give the child a name which intimated that the child would not do any harm, notwithstanding its strong vintana. Hence such names as Itsimanosika, ${ }^{1}$ Itsimandràtra, ${ }^{2}$ Itsimaniho, ${ }^{8}$ Itsimanolaka, etc., all expressing in a gencral way that the child would be harmless. Those born on the and of Addlo were often called Itsimarofy ("One who is not ill"), to avert the danger of dumbness.

Not only were the twenty-eight days of the month called after the month-names (and also after the moonstations), but, as already mentioned, a Hova house of the old style had also its sides and corners named after the

\footnotetext{
1 One who does not push.

2 One who does not hurt.

One who does not elbow.

- One who does not weaken.
} 
same fashion, beginning with the first month-name, Aldhamddy, at the north-eastern corncr, that is, the sacred part of the house, where the family charm was placed, and where prayers and invocations were offered. The inmates, on cach day, had to take particular care not to go to the corner or side assigned to that particular day, or, at all cvents, not to place a sick person there, for, by so doing, they would provoke the spirit of that region. (Sce diagram herewith given.)

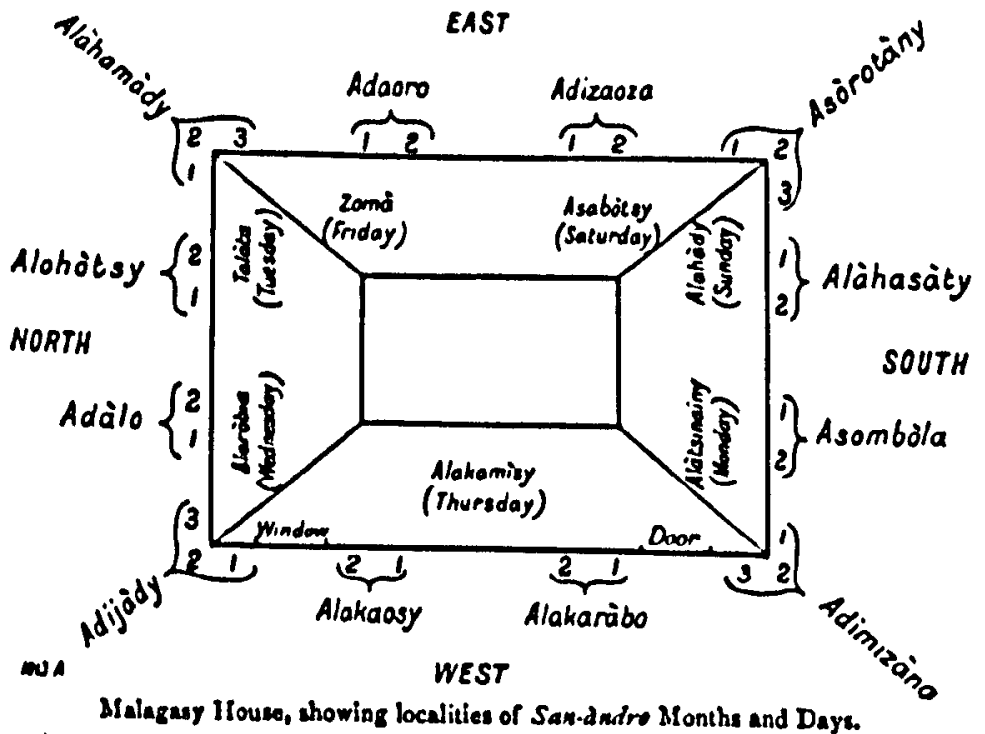

Mr. Dahle says that the vintana is really the key to the whole system of idolatry in Madagascar, and to cverything connected with it, at least so far as it got any real hold on the people; while the sikidy practice is also closely mixed up with it, although many points still need further investigation.

13.-The last division of the subject, that of San-dndro or Planetary Vintana, must be discussed very briefly. The word san-dndro, in its use among the Malagasy, means the peculiaritics or character of the days of the week' as depending on the Seven Planets, considered as governors of these days. The following is a list of the days of the 
Malagasy week, together with their respective san-dndro names, and their special numbers and characters :-

$\begin{array}{llllllc}\begin{array}{c}\text { English } \\ \text { Name. }\end{array} & \begin{array}{c}\text { Malagasy } \\ \text { Name. }\end{array} & \begin{array}{l}\text { San-indro } \\ \text { Name. }\end{array} & \begin{array}{l}\text { Arabic } \\ \text { Origin. }\end{array} & \text { Meaning. } & \text { Character. } & \text { Number. } \\ \text { Sunday } & \text { Alahàdy I } & \text { Samósy } & \text { Shams } & \text { Sun } & \text { good } & 1 \\ \text { Monday } & \text { Alatsinainy } & \text { Alakamary } & \text { Al-gamar } & \text { Moon } & \text { bad } & 5 \\ \text { Tuesday } & \text { Talata } & \text { Mariky } & \text { Marrik } & \text { Mars } & \text { good } & 2 \\ \text { Wednesday } & \text { Alarobla } & \text { Motarita } & \text { Utarit } & \text { Mercury } & \text { good } & 6 \\ \text { Thursday } & \text { Alakamlsy } & \text { Mosataro } & \text { Mushtari } & \text { Jupiter } & \text { bad } & 3 \\ \text { Friday } & \text { Zomd } & \text { Zohdra } & \text { Zahro } & \text { Venus } & \text { bad } & 7 \\ \text { Saturday } & \text { Asabòtsy } & \text { Johady } & \text { Zahal } & \text { Saturn } & \text { neutra } & 4\end{array}$

The fourth column of the above list gives the Arabic names of the Seven Planets, from which Mr. Dahle shows that the san-andro names of the wcek-days were clearly derived.

Anyone who has the slightest knowledge of Latin will see immediately that what were in Malagasy the extraordinary day-names, only used in san-dndro, were in Latin the ordinary day-names (Dies Solis, Luna, Martis, etc.); and their retention in part amongst modern European nations, with changes, as among oursclves, for Tcutonic god-names, for some days, is well known. The explanation, says Mr. Dahle, of this rather curious fact, no doubt, is that the astrology of Babylonia spread both to Arabia and from thence to Madagascar, and also to Europe; and that, according to this astrology, the planets in question, and the gods identified with them, held the sway over the days of the weck; and it depended on the supposed nature of each planet whether the day under its sway should be considered a lucky or an unlucky onc. Why such differences were supposed to result from the different

1 Mr. Dahle had previously shown (in Antaninarizo Annual, No. II, pp. 79-80) that these native names for the days of the week are of purely Arabic origin, the first five names being simply numerals from one to five, the first four being cardinals used as ordinals, and the fifth an ordinal ("One day", "Two day", etc.); the sixth is from Dschuma, "Congregation Day", the Sabbath of the Mohammedans; while the seventh is simply the Hebrew "Sabbath", slightly altered in spelling and termination. 
plancts it is very difficult to say; but we know that the notion of lucky and unlucky days has been tenaciously held by the common people in the different countries of Europe, and still retains its hold in many places.

It will be observed that the last column of the above list gives a certain number connected with cach day-name, and that these do not follow the order in which the days occur in the weck, except in the case of the first These numbers have, however, great importance in the practical part of san-dindro, as will be scen.

I. The San-dudro of the Dead, or Direct San-dndro.-This had reference apparently exclusively to burials; if a corpse was to be buried, it would probably be done on a "good" day (Sunday, Tuesday, or Wednesday); but the proceedings depended greatly on the mumbers characteristic of the san-dndro of that day. If, for instance, it was on Wednesday, the special number of which is $\sigma$, they had to stop six times with the bicr on the way to the grave, throw down a stone at cach stopping-place, and carry the corpse six times round the grave before they buried it. And so, mutatis mutandis, with the other days, according to their special numbers.

It is impossible, with our present knowledge, to say why these different days acquired their special numbers, as they do not follow the order either of the six or the brightness of the respective plancts. The Moon-day, it will be seen, is not No. 2 on the list, as might have becn supposed, but Na. 5 ; and the Venus-day is not No. 3, but No. 7.

2. The San-dndro of the Living, or the San-dndro which was counted "Backwards".- This appears to have had reference only to sacrifices; in offering these, the invocations made by the pricst referred, not to the san-dndro of the day the offering was made, but to that of "the day before jesterday", in other words, two days backward. Offerings. could only be brought on the three "good" days; but the sikidy could be performed on any day.

3. The Character of the Seven Days of the Week in rela- 
tion to Evils and the Foretelling of Evils. - The following rules were given to Mr. Dahle by his native "professor":

1. Sunday was the proper day for everything white: white-haired people, white stones, etc.

2. Monday: the day for everything green and blackish : grass, forests, greenish birds, people with blackish skin, ctc.

3. Tuesday: the day of pcople who have many scars, and are marked from small-pox.

4. Wednesday: the day of women and everything female.

5. Thursday: the day of slaves.

6. Friday: the day of nobles and everything red (red or scarlet clothes, etc.), characteristic of the higher nobility.

7. Saturday: the day of young pcople and every. thing young.

So if a man suffering from some evil came to a diviner on a Sunday, he would be told that his complaint had been caused by some white stone; or by drinking milk, in which there were some ghosts; or that he had been bewitched by some white-haired woman; or, at any rate, that he was in danger of some such mishap, and had better look out carefully. If he came on Thursday, his trouble was almost sure to be attributed to some slave, or he was warned to beware of his slaves, lest they should murder or bewitch him. And so on, for the other days, according to the nature of the day.

4 Foretclling of the Tdsik' dndro, i.e., the day on which one may be in special danger of getting ill through the innuence of the vintana. - This division of the san-dndro was a peculiar compound of vintana and sikidy subjected to certain rulcs, by which, beginning with Tucsday, different columns in the sikidy point to the different days of the weck; e.g., if a combination of the two columns Trdno and Ldlana in the sikidy erected gives a figure which is like vol. III. 
Tale (which represents the man in question), he is in danger of being taken ill on Tuesday. If the figures in Lalane and Mpdnontiny are like Tale, Wednesday is the unlucky day for him; and so on with other combinations. It is needless here to detail the remedies for these sup. posed evils.

Mr. Dahle says in his concluding sentence: "The sikidy and vintane was once the most tremendous power in Madagascar ; let us thank God that its spell is broken, and its influence passing away." I fancy there are few who will not say "Amen" to that sentiment; for whatever may be the interest which these old Malagasy customs have for us as students of folk-lore and humanity (and I venture to think that Mr. Dahle's rescarches are full of interest), we must surcly rejoice that such a system of folly and credulity on the one hand, and of trickery and deccit on the other, is losing its hold over the most influential tribe of Madagascar, the pcople who have gradually become the dominant race of the island. Andy I trust I shall be pardoned when, as a Christian missiontary, I remind you that the remarkable changes which have passed over the central provinecs of the great African island are the clirect result of the educational, the enlightening, and the purifying infuences which attend the proclamation of the Gospel of Christ. It was this which, from forty to fifty years ago, cnabled about 200 Malagasy believers to lay down their lives for their faith; it is this which is now, cspecially in the interior provinces, promoting cducation, forming an extensive literature, and furthering civilisation; and it is this alone which is slowly but surely lifting up the entire community to the level of an intelligent, enlightened, and Christian pcople.

JAMES Sibree. 